\title{
Identifying and Analyzing the Relevance of Prospective Science Teachers' Inquiry Abilities and Peers' Concept Understanding in Microteaching Course
}

\author{
Suciati $^{1}$, Riezky Maya Probosari ${ }^{1}$ \\ ${ }^{1}$ Science Education Department, University Sebelas Maret
}

\begin{abstract}
Question is one of the media that can be used by science teachers to train inquiry students' abilities. Interaction between teacher and students through inducement questions can be known how extent of science teachers' inquiry abilities in the implementation of inquiry-based teaching. The purpose of the study was to identify and analyze the relevance of prospective science teachers' inquiry abilities and peers' concept understanding in the implementation of inquiry-based teaching. This study is descriptive research design involved 10 prospective science teachers of Biology Education Department at a state university in Surakarta who joined microteaching course. The data were qualitatively and descriptively in search of ways that could describe in the observed prospective science teachers' inquiry abilities in the implementation of inquiry-based teaching. The prospective science teachers' inquiry abilities illustrated how their questions as a trigger to engage peers' questions rising when interaction with peer students. Data of peers' concept understanding illustrated how their concept understanding on cognitive assessment. Data collected by interview, observation, and documentation. The results showed in general the inquiry abilities of prospective science teachers and peers' concept understanding was low categories. Based on the results, it can be concluded that prospective science teachers' inquiry abilities relevant with peers' concept understanding.
\end{abstract}

Keywords: inquiry-based teaching; microteaching; prospective science teachers 'inquiry ability; peers' concept understanding

\section{INTRODUCTION}

Making the lesson plan and its implementing is a part of pedagogic competency as a professional teacher beside, assessing, conducting guidance and training, research, and assisting the development and management of schools (Depdiknas, 2004). Preparing professional teachers needs good debriefing for prospective teachers. Besides equipped with science also need to be equipped with other competences such as pedagogic, personality, professional and social. It is in accordance with Indonesian Government Law No 19/2005 about national education standards. One of the provisions that can be done to prepare a professional teacher is through microteaching activities. It is according with the statement [1,2] Which states that Microteaching provides pre-service teachers with a connection between theory and practice and improves their teaching skills with regard to planning, implementation and evaluation. 
Microteaching is an effective teaching method that is used for the professional development of pre-service and in-service teachers [1,3]. Allen and Ryan [4] stated that microteaching improves the teaching skills of pre-service teachers by reducing the complexity of the authentic classroom environment and limiting content, time, and the number of students. Microteaching is used in the field of therapy, [5], to help convert theoretical knowledge into practical applications during interaction with patients. Microteaching is an innovative method for preparing teachers for effective, skills, and practical needs [6]. Microteaching is an excellent way to build up skills and confidence, to experience a range of lecturing/tutoring styles and to learn and practice giving constructive feedback. Microteaching gives instructors an opportunity to safely put themselves "under the microscope" of a small group audience, but also to observe and comment on other people's performances [7].

A microteaching session is much more comfortable than real classroom situations, because it eliminates pressure resulting from the length of the lecture, the scope and content of the matter to be conveyed, and the need to face large numbers of students, some of whom may be inattentive or even hostile. Another relevance of microteaching is that it provides skilled supervisors who can give support, lead the session in a proper direction and share some insights from the pedagogic and andragogy view. Microteaching considers the trainee's capacities by allowing him to select the content of the lesson from the area of his greatest competence (Meier, Summer 1968 [8]).

Guidance of prospective teachers in micro learning should be directed to the establishment of teacher competence as a learning agent as mentioned above. Therefore, teachers must obtain adequate supplies to be able to master a number of these competencies, either through preservice or in-service training. One form of preservice training is the formation of teaching skills (teaching skills). In practice, the provision of teaching skills can be trained through micro teaching activities or micro learning.

According to Foley [9] the pedagogic skill for teaching can be acquired only through more structured and cheaper faculty training techniques. With the introduction of microteaching about five decades ago, the lacunae of scientifically proven or effective methods to be followed in teacher training programs has been overcome [10]. One of the pedagogic abilities that teachers must master is able to choose the appropriate learning method with the curriculum, the characteristics of the students, connected with daily life, etc.

The nature of science learning refers to three things namely hands on, minds on, and hearts on [11]. As biology teacher should be able to choose methods that are in accordance with the nature of learning science. One of the learning models that is in line with the curriculum and the nature of science is the inquiry learning model. Inquiry activity is the soul of science teaching. Inquiry activity is not only oriented towards product but also the process of the scientific knowledge achievement $[12,13]$. Science learning-based inquiry, students are required to be able to ask a scientific question correctly, get corroboration of prior knowledge and the results of the investigation, suggested explanations based on evidence and reason logically, and make their conclusions to confirm the results of his thinking [14, 15]. According Duschl, et al. [16] that in established a scientific explanation; students are required to present evidence to support the claims and the language and scientific ideas to describe their reasons. Thus in providing claims, evidence, and reason requires a high 
level thinking skills such as logical thinking, critical and analytical to produce a scientific explanation. This is relevant to Levy et al. [17] that the ability to scientific communication designed to improve the scientific literacy and skills of learning science.

\section{RESEARCH METHOD}

This study is a descriptive research design involved 10 prospective science teachers of biology education department at a state university in Surakarta who joined microteaching course. The data were qualitatively and descriptively in search of ways that could describe in the observed prospective science teachers' inquiry abilities in the implementation of inquiry-based teaching. The prospective science teachers' inquiry abilities illustrated how their questions as a trigger to engage peers' questions rising when interaction with peer students. Assessment of questions is done by recording the types of questions that arise and then analyzed quantity and quality based on inquiry indicators according to Exploratorium [18] include: 1 . The ability to weigh and ask questions that are investigable; 2 . Ability to ask how answers to questions can be found; 3 . The ability to change non investigable questions into actionable questions. using the rating rubric using Likert scale. Data of peers' concept understanding illustrated how their concept understanding on cognitive assessment using content learning content test. Data collected by test technique to assess peers' concept understanding on cognitive ability and non-test technique thorough observation, interview, and documentation.

\section{RESULT AND DISCUSSION}

\section{Findings}

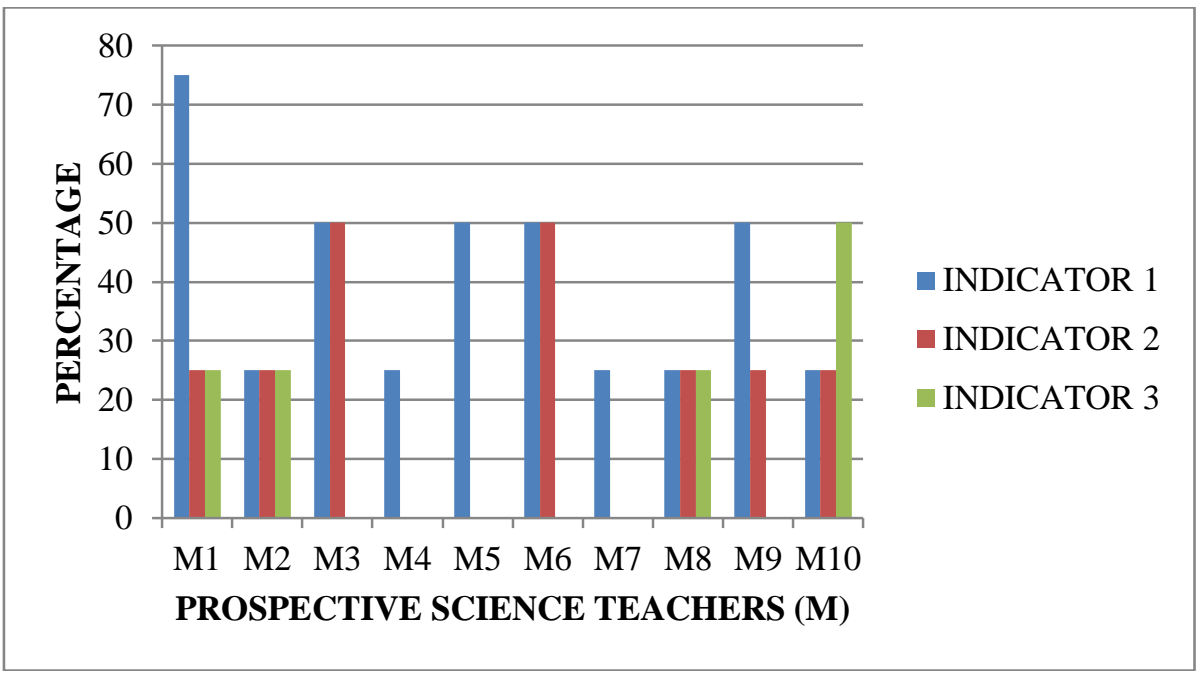

Figure 1. Quality of Prospective Science Teachers' Inquiry Abilities 


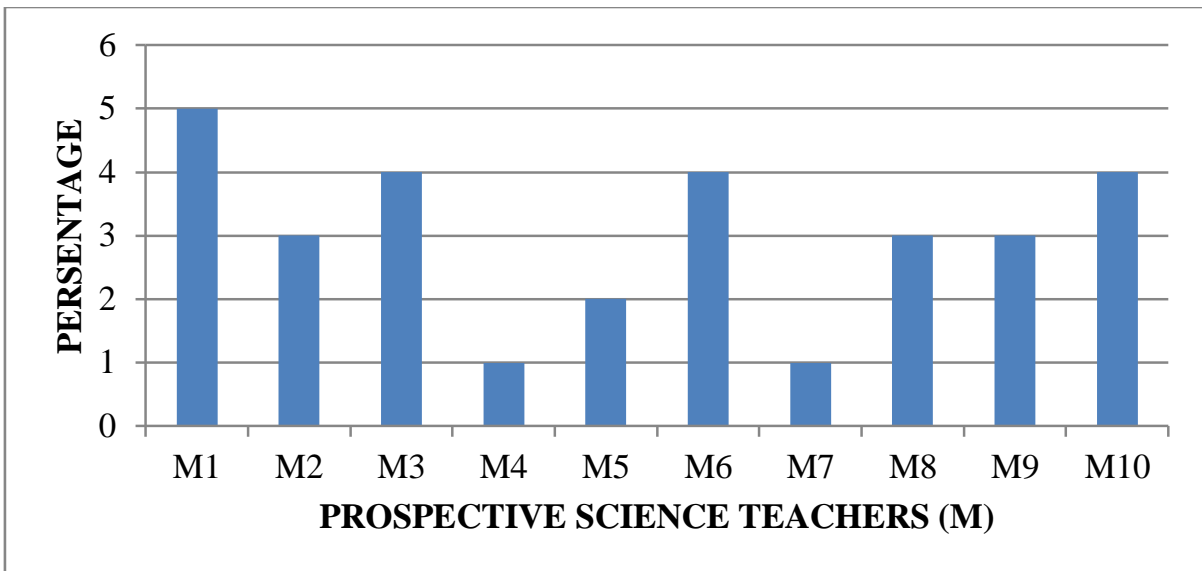

Figure 2. Qualitative of Prospective Science Teachers' Inquiry Abilities

\section{Peers' Concept Understanding}

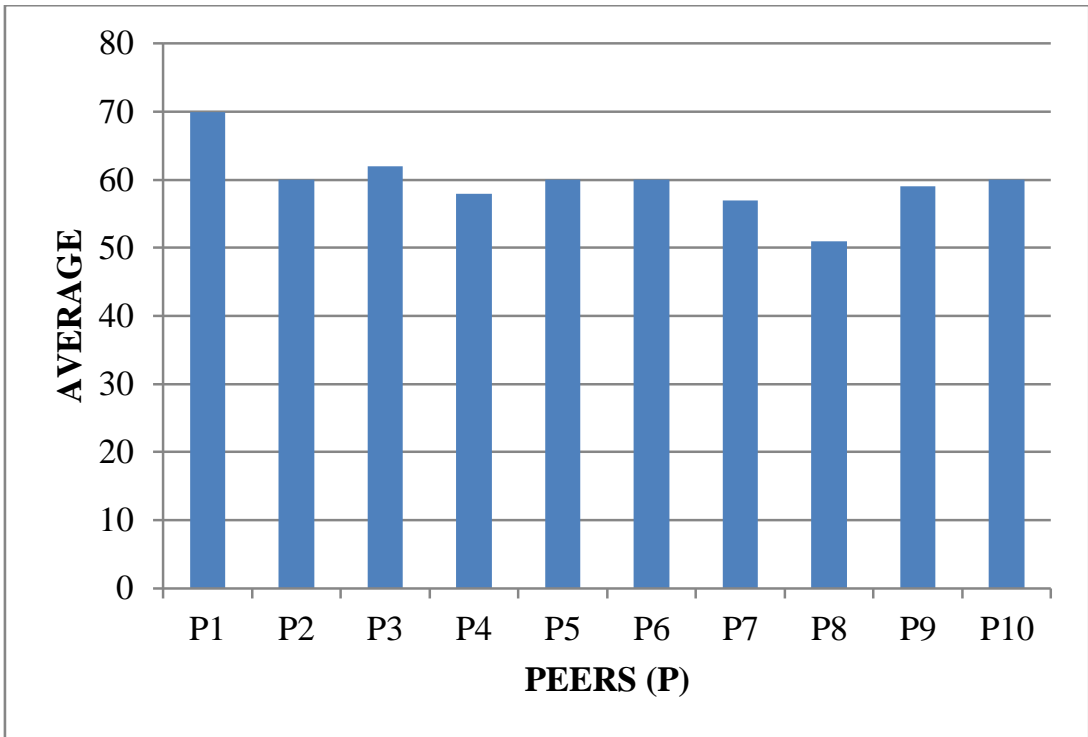

Figure 3. Peers' Concept Understanding

\section{Discussion}

The data in Figure 1 shows that the average quality of inquiry skills of prospective teachers is not yet optimal. Inquiry capability that has been mastered by prospective teachers in general is the indicator 1 is the ability to weigh and ask questions that are investigable. While there are 3 prospective teachers (M4, M5, M7) who have not been able to master the indicator 2 is the ability to ask how answers to questions can be found. While the indicator 3 is the ability to change non-investigable questions into actionable questions, can only be mastered by 4 prospective teachers (M1, M2, M8, M10). Prospective teachers most master the indicator 1, this means that in general the quality of inquiry skills of prospective teachers fall into the low category. 
The data in Figure 2 shows that the average quantity of students' inquiry skills varies. The number of inquiry questions posed by prospective teachers is mostly shown by M1 (5). M3, M6, and M10 can ask 4 inquiry questions. Prospective teachers (M2, M8, M9) present 3 questions. The ability of inquiry that has been mastered by prospective teachers in general mem M5 only able to ask 2 questions. While M4 and M7 are only able to ask questions. In general, the quality of inquiry skills of prospective teachers fall into the low category.

The success of inquiry is not separated from the previous knowledge. Students who diligently read scientific articles and other learning resources tend to be more successful than those who do not [19]. The achievement of the average score of peers' understanding only reached $60 \%$. This can mean the result is not maximized. Based on these data it can be argued that the quality and quantity of inquiry skills of prospective teachers have an impact on understanding peers concept. Research result [20] shows that: there is a significant positive relationship between teacher inquiry knowledge of the content of science materials with the ability to make learning planning inquiry. In addition, it is also found that the skill in making inquiry planning contributes significantly to the inquisitor's ability to teach science. In line with [21] which state that if the knowledge of teachers in science learning inquiry is good, then it can improve the ability to teach science well.

Based on the data obtained above it is necessary education that trains prospective teachers to be able to implement learning using IBT. This is in accordance with research conducted by [22], resulted in the ability of teaching through the use of inquiry of teachers in Southern Nigeria, the idea that the ability to teach better by using inquiry. Inquiry learning is important in science because inquiry helps students to discover knowledge through learning experiences. It is in line with Pedaste et al.[23] who argued that inquiry-based learning involves students in an authentic scientific discovery process, in which complex scientific processes are split into smaller, interconnected and thinking-thinking units.

\section{CONCLUSION}

Based on the results, it can be concluded that prospective science teachers' inquiry abilities relevant with peers' concept understanding. The ability to implement the prospective teacher's IBT has an impact on peer knowledge. Microteaching should train prospective teachers to implement inquiry-based learning, so that students can easily understand the concept of the material being taught. Prospective teachers who have Prospective Science Teachers' Inquiry Abilities can either serve as models for other teacher candidates in implementing inquiry-based learning.

\section{REFERENCE}

[1] Fernandez, M. L. (2005). Learning through microteaching lesson study in teacher preparation. Action in Teacher Education 26, 37-47.

[2] Gress-Newsome, J. \& Lederman, N. G. (1990). The pre-service microteaching course and science teachers' instructional decisions: A qualitative analysis. Journal of Research in Science Teaching 27(8), 717-726.

[3] Kpanja, E. (2001). A study of the effects of video tape recording in microteaching training. British Journal of Educational Technology, 32(4), 483-486. 
[4] Allen, D. \& Ryan, K. (1969). Microteaching. Reading. Massachusetts: Addicson-Wesley Publishing Company.

[5] Mastromarino, R. (2004). The use of microteaching in learning the redecision model: A proposal for an observation grid. Transactional Analysis Journal, 34, 1, 37-47.

[6] Ambili, R. 2013. Microteaching, an efficient technique for learning effective teaching. Journal of Research in Medical Sciences, 18(2), 158-163.

[7] Anthonia , Otsupius, I. 2014. Micro-Teaching: A Technique for Effective Teaching. An International Multidisciplinary Journal, Ethiopia Vol. 8(4), 183-197.

[8] Cooper, J. M \& Allen, D .W. (1970). Microteaching: History and Present Status. ERIC Clearinghouse on Teacher Education, Number One Dupont Circle, N.W. Washington, D.C.

[9] Foley RP. Microteaching for teacher training. Public Health Pap. 1974;61:80-8.

[10] Elliot J. A microteaching experiment at MEDUNSA. S Afr Med J. 1982;62:868-70.

[11] Arends, R.I. 2008. Learning toTeach. Yogyakarta: Pustaka Pelajar.

[12] Bevins, S., \& Price, G. 2016. Reconceptualising inquiry in science education. International Journal of Science Education, 38, 17-29.

[13] Palmer, D. H. 2009. Student Interest Generated During an Inquiry Skills Lesson. Journal of Research in Science Teaching, 46, 147-165.

[14] Bell, T,,Urhahne, D., Schanze, S., \&Ploetzner, R. 2010. Collaborative Inquiry Learning: Models, Tools, and Challenges. International Journal of Science Education, 32(3), 349-377.

[15] Rinehart, R. W., Duncan, R. G., Chinn, C. A., Atkins, T. A., \& Dibenedetti, J. 2016. Critical Design Decisions for Successful Model-Based Inquiry in Science Classrooms. International Journal of Designs for Learning, 7(2), 17-40.

[16] Duschl, R., H.A.Schweingruber, \&Shouse, Eds. 2007.Taking Science to School: Learning and Teaching Science in Grades K-8. Washington DC: The National Academies Press.

[17] Levy, O. S., B. Eylon, \& Z. Scherz. 2008. Teaching Communication Skills in Science :Tracing Teacher Change. Teaching and Teacher Education, 24 : 402-477.

[18] 18. Exploratorium. (2006). Process Skill. Exploratorium, San Francisco [online] diakses melalui : www.exploratorium.edu/ifi/workshops /fundamentals

[19] Probosari, R.M., Ramli, M., Sajidan. 2015. Dampak Pembelajaran Inkuiri Berjenjang Dalam Meningkatkan Keterampilan Menulis Argumentatif Calon Guru. Jurnal Pengajaran MIPA, Volume 20, Nomor 2, Oktober 2015, hlm. 155-162.

[20] Luera \& Moyer. (2004). Effectiveness of Professional Development Program on a Teacher's Learning to Teach Science as Inquiry. University of IOWA Departement of Science Education. Asia Pacipik Forum k Forum on Scie

[21] Budiastra, K. (2008). Core Business Pembelajaran IPA: Meningkatkan Kreativitas Guru Mengajar IPA dengan Inkuiri di SD dalam Kontek Pendidikan Jarak Jauh. (Jurnal). Disampaikan pada Seminar International II Pendidikan Sain. "Current Issues on Research and Teaching in Science Education". Disertasi. Bandung: Sekolah Pascasarjana Universitas Pendidikan Indonesia. Tidak Diterbitkan.

[22] Iyamu \& Ottote. (2005). Focus on Inquiry. A Teacher Guide to Implementing Inquiry- Based Learning. Canada: Alberta.

[23] Pedaste, M., Maeots, M., Siiman, L., de Jong, T., van Riesen, S., Kamp, E., Manoli, C., Zacharia, Z., \& Tsourlidaki, E. (2015). Phases of inquiry-based learning: Definitions and the inquiry cycle. Educational Research Review Vol. 14 No.1, hlm. 47-61 